\title{
Innovative Research On Project-based Teaching for Software Technology of High vocational Education and Its Application
}

\author{
Jing Li \\ College of Information Engineering, Wuhan Internetional Trade University, \\ Wuhan 430205, China \\ Email: qingeast@163.com
}

\begin{abstract}
Keywords: project-based teaching; semester project; collaborative teaching; innovation; High vocational Education; software technology major
\end{abstract}

\begin{abstract}
Currently, there are a lot of researches on project-based teaching for software technology of High vocational Education, these researches mainly take one curriculum as the carrier and received some achivements. However, due to the lack of collaboration of professional courses related project and adequate comprehensive trainings, students often can not master software development skills fastly and entirely. Base on the analysis of the status quo and deficienty of project-based teaching, the author proposed an innovative mentality, taking the semester project as the core, team teaching in related courses, and then achieving progressive layers of semester projects. The reseach involves curriculum system, teaching design, teaching organization, evaluation system, and information platform, then put these studies into teaching practice, and achieved some success.
\end{abstract}

\section{Introduction}

Project-based teaching is the student-centered, will impart knowledge-based traditional teaching changed to complete the project, vocational experience and problem-oriented multidimensional interactive teaching. Students practice through projects, understand and master the professional knowledge and skills, experience hands-on course to complete the project, to be stimulated interests in learning and innovative thinking, develop comprehensive ability such as problem analysis, problem solving, teamwork, effective communication and so on.

\section{Project-based teaching and Software technology of High vocational Education}

A. The characteristics of Project-based teaching

The most significant features of project-based teaching is "project-based line, teacher-led, student-centered", focusing on the training of technical proficiency to students, focusing in conjunction with the work process, focusing on guide students to finish tasks spontaneously, and then develop comprehensive ability training through practicing project.

B. The training objectives of Software technology in High vocational Education

Software technology in High vocational Education is to serve for the community, taking the employment as the guidance, and train high-quality skilled professionals meeting the job demands of software development, software technical support and service, and other IT companies.

C. Project-based teaching and Software technology of High vocational Education

The Characteristics of Project-based teaching determine that it has broad application space in Software technology of High vocational Education. Using project-based teaching in Software technology speciality, can create vocational scenarios of software development process for students, improve students' ability of knowledge applications, enhance professional comprehensive literacy, reduce the gap between the school and social work, and promote rapid induction of students. 


\section{The application status and problems of Project-based teaching in Software technology of High vocational Education}

There are already a lot of vocational colleges conducted the research of project-based teaching, providing guidance for the current teaching and achieved some success. But there are still some problems.

A. At present,most of vocational schools take single curriculum as unit for project-based teaching,they put some functional modules of project interspersed in the curriculum for teaching, the integrity and growth of the project are not be reflected; sometimes one curriculum involves multiple projects, and some modules of a project may also be interspersed in many courses.Due to the lack of curriculum coordination, resulting in fragmented teaching cases even messy, students can't focus the development of one project.

B. The majority of students is one-sided consciousness, they focus solely on software development, and despise software requirements analysis, modeling, documentation writing, software testing, let alone software maintenance, software upgrade.So, many students can not deeply and detailly understand the various processes of software development , and limited in rough understanding. While grouping often used to simulate division of work in project-based teaching,so, some problems occur when division of labor and project cooperation.

C. Project appraisal usually implements basically on single curriculum. Sometimes, students need finish more than one project to complete the assessment of different professional courses in a semester, resulting in certain cross-examination between curriculums, not only increases the burden of student assessment, but also reduces the quality of students' pursuit of the project.

D. The homework of each course is often much different, so it is difficult for student to focus on the development of one project, but increase the extracurricular burden, and not conducive to students' achievement and interest in learning.

E. Though some schools set a comprehensive training course, but students often feel difficult to digest and master project development skills completely through one course.

Through the analysis, the author believes that there are two key reasons which lead to the above questions. First is the lack of synergy across various professional curriculums, the second is that the comprehensive training integrated to various professional courses is much lacking.

\section{The innovative research on project-based teaching for Software technology of High vocational Education and its application}

Aiming at the existing problems in project-based teaching, the author led the team conduct innovative research on project-based teaching in software speciality, adopting a semester project as the core, teaching synergistically in various professional courses, and forming the progressive layers semester projects,and thus to make the project-base teaching more efficient in software technology of High vocational Education.

A、 The restructuring of professional practice curriculum system and reform.

According to the students' cognition,the logical development of knowledge, the rising curve of Occupation post ability,the team make unified planning of multiple courses each semester,taking the semeter project as emphasis, project development capabilities as the core.In the plan,professinal courses each semester common revolve round one semester project,and then form modular curriculum links which take different types and levels layer projects as traction, thus make programming skills promoted step by step through a number of integrated projects from easy to difficult. At the same time, the concentration project practice is setup at the end of each semester, students can finish the whole project centrally which is dispersed in the previous courses,not only realize the target of review, consolidation, improvement even innovition, but also facilitate soft products which make student become more and more confidence and encouraging. 
B、The design of project-based teaching content

a、 The selection of project is the key

The term projects selected should have the following characteristics: professional authenticity, openness, feasibility, comprehensive, and progressive. Professional authenticity refers to the project stem origins from real life, with more actual development demands and potential applications. Openness refers malleable, inspiring, not only to represent one category project which can implement laterally expand training by students combining their interest, but also to achieve vertical expand training through improvement of project function spontaneously; Feasibility refers to that the projects selected can be independently completed by students with the guidance of teachers, considering the conditions of the practice, the students' learning situation, and the approporiate difficulty. Comprehensive refers to seleted projects can able to reflect and include most of the corresponding knowledge, skills and methods of professional competence required, and reflect the software development process. Progressive means to achieve multi semester projects from easy to difficult step by step, so that students can gradually master project development skills, and gradually improve the overall quality and enhance employ ability.

b、 Project function and course content are emphasis.

First,with the guidence of teacher, the students and teachers common complete the demands analysis of each semester project.Second, the teachers of relevant professional courses cooperate to analyze project functions and make detailed plans,define a clear position and role of the various courses in the semester project, and decompose corresponding functional module into various courses, each course again decompose sub functional module into various chapters, sort knowledge, skills and form a number of individual cases,thus realizing the " project coursed, courses cased".

C、 The organization of project-based teaching is the core

The goal of the organization of project-based teaching is to enhance the team teaching force, improve students' ability of the project development and vacational comprehensive ability.So, on the one hand, Teachers cooperate with each ther on implementing project teaching plans, unifying basic teaching schedule, timely communication, mutual cooperation, and then give full play to the strength of teacher teams. And some company's engineers or experts will be timely invited to guide the project teaching. On the other hand, students will be directed and guided in project practicing, focusing on project development capabilities.

There are some specific ways to take as follows. First, projects teaching is combined with the traditional teaching, taking the knowledge as the main line, using case teaching, task-driven method, not only can cover most of basic knowledge, complete foreshadowing teaching project, but also can highlight the case in class, guide students complete project step by step .Second, organizing extracurricular project development interest groups among students, is an effective complement to teach in class, through extracurricular project practice autonomously, students' comprehensive ability and professional ability can be enhanced better and faster.Third, each semester project uses two-stage teaching that first stage is to study courses corresponding project function module,second stage is to concentrate finishing the comprehensive project in all courses, in process of concentration project practice, students can cultivate comprehensive abilities.Fourth , the beginning simple project must be finished by each student independently, convenient for students to fully grasp the theory of knowledge, in-depth understanding of the project development process, familiar with the corresponding job requirements, advance thinking and develop career plans, and lay the foundation of division of labor in the subsequent complex semester project ; the later complex project adopts grouping and role-playing method which provides students real vocational scence,this simulate work will set up a bridge leading to employment from the school for students.

D、Constructing a reasonable and open evaluation system of project-based teaching

In order to highlight cultivation of comprehensive ability for students, a bundled assessment method which is project-centered and emphasizes the process assessment of each course is used.The score of each course is proportional composed of three parts, usually score is $20 \%$, process score is $30 \%$ and final score is $50 \%$. Usually score mainly include attendance, discipline, attitude and so on; process score is weighted unit results of each course; final score is replaced by the semester project 
results. To some extent, project results largely determines the results of various courses. What's more, assessment platform shifts to online, and truly reflects openness, fairness and impartiality. So, exam tends to become a better tool to test project development capabilities of students, a driving force to study, the source of innovation.

E、 Constructing integrated practice platform of project-based teaching

Teachers collaboratively build practice teaching platform, standardized management, enriching resources related projects, and evaluation system. At the same time to take every student especially each session of outstanding students of advantage, absorb outstanding works and make students to become the main member together with teachers to enrich resource platform.

\section{The results achieved}

The above Research on project-based teaching began in March 2012 and applied for the 2011 grade of the students.At present, the students have entered the stage of practice. From the response of students,teachers,schools and social, not only the students' project development ability but also the students' comprehensive ability and innovative thinking is greatly improved. The following table shows some datas of the 2011 grade of the students and the previous two grades of students, and the memorabilias which reflect the comprehensive ability of the 2011 grade of student.

Table 1.Student teaching effect

\begin{tabular}{|c|c|c|}
\hline NO. & The item compared & $\begin{array}{l}\text { The growth rate of the } 2011 \\
\text { grade students than the previous } \\
\text { two grades of students }(\%)\end{array}$ \\
\hline one & The number of finished projects in college & $\uparrow$ two hundreds \\
\hline two & $\begin{array}{l}\text { The ratio of students participation enterprise real } \\
\text { project in college }\end{array}$ & $\uparrow$ twenty-two \\
\hline three & The ratio of students finished projects each stage & 个eighteen \\
\hline four & The professional counterparts rates in pratice stage & $\uparrow$ twenty-one \\
\hline five & $\begin{array}{l}\text { The ratio of students crossing language } \\
\text { programming }\end{array}$ & $\uparrow$ eight \\
\hline $\operatorname{six}$ & The rate of Enterprise good feedback & $\uparrow$ twleve \\
\hline
\end{tabular}

Table2. The campus memorabilias among the 2011 grade students

\begin{tabular}{|c|l|}
\hline NO. & \multicolumn{1}{|c|}{ memorabilias } \\
\hline one & $\begin{array}{l}\text { In September 2012, The students of } 2011 \text { grade created the computer association of } \\
\text { college, many students in this grade are the main members and the main organizer of } \\
\text { association, and they play a key role in community work. }\end{array}$ \\
\hline two & $\begin{array}{l}\text { In March 2013, The students set up software studio together with teachers; they } \\
\text { implement project development after school. }\end{array}$ \\
\hline three & $\begin{array}{l}\text { In November 2013, The students spontaneously organized the first software } \\
\text { professional graduation party, showed the multi-language programming project such } \\
\text { as c\#, Java, ASP, Internet of things. }\end{array}$ \\
\hline
\end{tabular}

At the same time, through team teaching, teachers greatly improved in the work level of teaching and scientific research. First, the evaluation of university supervisor to teachers improved; second, the teachers' ranking of the work assessment in academy nearly two years is advanced; third, the number of papers and research subjects is increasing.

In a word, through the reform and innovation on project-based teaching, formed a mode which take a semester project as the core, conduct teaching collaboratively, it is more effective than before, what's more, it provide students and teachers a broader space to improve. 


\section{Conclusion}

Project-based teaching is complex and flexible, it does not have the same teaching material, which requires professional teachers have sufficient strength in project development and give full play to the spirit of co-teaching, as well as providing rich project resources for students, and actively guide them to learn and innovate independently, exercise practical ability, and ultimately provide students a smooth transition from the school to the jobs.

\section{Acknowledgements}

This work is supported by Hubei Provincial Department of Education under Grant 2013B398, the title of subject is "Layer type project Research on the practical teaching reform for software technology in High vocational educaton". It is one of subjects of Education Science "Twelve Five" projects.

\section{References}

[1] Liaochen Xing. Research on Project Teaching in High Vocational education and its Practice. Nanchang Junior College, Febrary 2010, p.121-122.

[2] Chen Xuhui, Zhang Rongsheng. Project Development and instructional design of Project-based teaching and its application. Vocational and Technical Education of China, March 2009, p.59-61.

[3] TuLiGuRi, Chen Baofen. Problems and Solutions of project teaching in High Vocational colleges. Vocational and Technical Education of China. September 2008, p.55-57.

[4] Bao Fang, Wu Zhong. Research of Curriculum Implementation of Polytechnic Course.Computer Education, 2008, (20), p183-185.

[5] Wu Jiali, Xu Fangkui.Innovative Research On occupational competency-based talents training mode of High vocational Education. Education and Career.2010, (32), p.26-28. 